\title{
STUDY ON THE THERMAL PARAMETERS' DETERMINATION METHOD OF ULTRA SUPERCRITICAL THERMAL POWER GENERATING UNITS
}

\author{
Jian-xing REN, Fang-qin LI, Qiguang SHI, Jiang WU, Qun-zhi ZHU, Wei-guo PAN, Qi-fen LI
}

Energy and Environment Engineering Institute, Shanghai University of Electric Power, Shanghai 200090,China

\begin{abstract}
Supercritical and ultra supercritical thermal power generating units are the major development power generating units. The main steam parameters of thermal power generating units directly affect on the generating efficiency and pollutant emission. In this paper, the state-of-the-art of oversea supercritical and ultra supercritical thermal power generating units was analyzed. Under the condition of the domestic technology and manufacture capacity, and based on the generating efficiency and unit performance meeting of requirement, the thermal parameters' determination method of ultra supercritical thermal power generating units was studied. Main steam pressure is generally less than $27.56 \mathrm{MPa}$, and the temperature of main steam and reheated steam is about $600^{\circ} \mathrm{C}$.
\end{abstract}

Keywords: Ultra Spercritical, Coal-fired Generating Unit, Thermal Parameter

\section{INTRODUCTION}

In China, coal as main primary energy is used highly, especially by electric power industry. Now, in China, the installed gross capacity of electric power has been up to 6 hundred million $\mathrm{kW}$. But, the ratio of the coal-fired unit, whose unit capacity is less than $100 \mathrm{MW}$, is very high. Subcritical $300 \mathrm{MW}$ coal-fired units are about $50 \%$. Average power supply coal consumption is very high. The development of integral technology and economy is severely affected $[1,2]$.

Now, with the development of generating unit from $300 \mathrm{MW}, 600 \mathrm{MW}$ subcritical generating unit to supercritical generating unit, in order to create the generating efficiency and energy utilization, rapidly develop high parameters and large capacity domestic supercritical and ultra supercritical thermal power generating units will be developed, and the unit capacity, design, manufacture, low energy consumption and low pollutant emission will be increased. This will be propitious to boost equipment manufacturing up to develop, to increase their international competition ability, make them economize limited energy and to advance the generating efficiency of generating unit. Based on the Chinese practical situation of power industry, in order to advance the technology of generating unit, it is necessary to develop the supercritical and ultra supercritical thermal power generating units. This is favor of improving Chinese power supply structure, the stability and economy of electric network peakload, unit efficiency, low coal consumption, low pollutant emission and good ecological condition [3, 4]. Now, with the national energy adjusting and environmental protection law promulgating, the supercritical and ultra supercritical thermal power generating units will be vigorously developed. To substitute supercritical and ultra supercritical thermal power generating unit for conventional coal-fired unit is a no time to delay task to finish.

\section{PRESSURE CONFIRMATION OF MAIN STEAM}

The parameters of coal-fired units mainly include main steam's temperature and pressure, and reheat steam's temperature and pressure. The development of supercritical and ultra supercritical thermal power generating unit is to increase electric efficiency and decrease electric energy consumption. Based on thermal circuit theory of thermal power generation, increasing of parameters is available method to increase the electric efficiency. Parameters are higher, electric efficiency is higher, and unit electric coal consumption is less. The relationship of thermal parameters and electric efficiency saw table $1^{[5,6]}$. From table 1 , main steam's temperature and pressure are higher, electric efficiency is higher. From subcritical unit to ultra supercritical unit, electric efficiency is increased to $6 \%$.

Table 1 The relationship of thermal parameters and electric efficiency

\begin{tabular}{|l|c|c|c|}
\hline Unit & $\begin{array}{c}\text { Temperature } \\
\left({ }^{\circ} \mathrm{C}\right)\end{array}$ & $\begin{array}{c}\text { Pressure } \\
(\mathrm{MPa})\end{array}$ & $\begin{array}{c}\text { Electric } \\
\text { efficiency } \\
(\%)\end{array}$ \\
\hline $\begin{array}{l}\text { High pressure } \\
\text { unit }\end{array}$ & 540 & 9.8 & $\sim 30.0$ \\
\hline $\begin{array}{l}\text { Super high } \\
\text { pressure unit }\end{array}$ & 540 & 13.7 & $34.0-35.0$ \\
\hline Subcritical unit & 540 & 17.3 & $37.0-38.0$ \\
\hline Supercritical unit & 569 & 25.4 & $41.0-42.0$ \\
\hline $\begin{array}{l}\text { Ultra } \\
\text { supercritical unit }\end{array}$ & 605 & 27.5 & $43.0-44.0$ \\
\hline
\end{tabular}


Under the initial steam pressure $\leq 25.0 \mathrm{MPa}$, conventional supercritical steam turbine can be universal. it is to say that the design and manufacture of cylinder and rotor can be homemade. Of cause, the design of through-flow part, especially final titanium alloy blade part accessories such as valve and material, depends on import.

Under the initial steam pressure higher than 25.0 $\mathrm{MPa}$, the design and manufacture of ultra supercritical unit must be cooperative with other nation. There is difference of deferent foreign cooperation. Based on outstanding achievement of main Multinational Corporations, it indicates that: Japan TOSHIBA, HITACHI and MITSUBISHI Co., SIEMENS Co., ABB Co., and ALSTOM Co. have ability of design and manufacture of supercritical and ultra supercritical unit. So, to choose the unit's pressure, it must consider the operation achievement of Corporation Co., as well as the capacity of design and manufacture and technology accoutrement of internal manufactory, material supply and manufacture, and nationalization. Now, the pressure of mature unit is less than $27.56 \mathrm{MPa}$. In YUHuan power plant, there are $4 \times$ $1000 \mathrm{MW}$ ultra supercritical coal-fired units, which were introduced into China as "863 plan". Boilers were made by Harbin Boiler Company Limited, and MITSUBISHI Co. offered technical support. The BMCR is $2953 \mathrm{t} / \mathrm{h}$, main steam pressure is $27.56 \mathrm{MPa}$. Steam turbine was made by Shanghai turbine Company Limited and generator made by Shanghai turbine generator Company Limited, and SIEMENS Co., offered technical support. Steam turbine is ultra supercritical, primary reheat, uniaxial, four-cylinder and quadruple-flow, double backpressure, condensing, eight stage backheating extraction, normal rated power $1000 \mathrm{MW}$, steam pressure $26.25 \mathrm{MPa}$, generator name-plate power1000MW, water-hydrogen-hydrogen cooling-down method[7].

In Shandong Zouxian power plant, there are $2 \times$ $1000 \mathrm{MW}$ ultra supercritical coal-fired units. Boilers were cooperatively designed and manufactured by Dongfang Boiler Company Limited, Japan Babcock- HITACHI Co. and Dongfang-HITACHI I Co. BMCR is $3022 \mathrm{t} / \mathrm{h}$, main steam pressure is $26.25 \mathrm{MPa}$ [8].

\section{CONFIRMATION OF MAIN STEAM TEMPER- ATURE AND REHEAT STEAM TEMPERATURE}

Besides of the main steam pressure, increasing of main steam temperature and reheat steam temperature is other method to reduce energy consumption and advance the electric efficiency. Based on thermal circuit theory of thermal power generation, under the same condition of steam temperature, the thermal efficiency of $24.1 \mathrm{MPa}$, steam pressure supercritical unit is $1.7 \%$ higher than that of 16.6 $\mathrm{MPa}$ subcritical units. If reheat steam temperature is increased from $538^{\circ} \mathrm{C}$ to $566^{\circ} \mathrm{C}$, thermal efficiency will be increased $0.8 \%$ again, and total unit efficiency will be increased $2.5 \%$. if steam pressure is same $24.1 \mathrm{MPa}$, main steam/reheat steam temperature is increased from $538 / 566^{\circ} \mathrm{C}$ to $600 / 600^{\circ} \mathrm{C}$, the unit electric efficiency will be increased about $3.1 \%$. When main steam temperature is up $10{ }^{\circ} \mathrm{C}$, the increasing of unit electric efficiency see table 2 . From Table 2, when main steam temperature is up $10^{\circ} \mathrm{C}$, the unit electric efficiency of one or double reheat units can be increased $0.55 \%$. So, we can saw that increasing of steam temperature is benefit to electric efficiency.
Table 2 Increasing of unit electric efficiency with main steam temperature up $10^{\circ} \mathrm{C}$

\begin{tabular}{|l|c|c|c|}
\hline & $\begin{array}{l}\text { Main } \\
\text { steam }\end{array}$ & $\begin{array}{l}\text { Primary } \\
\text { reheat steam }\end{array}$ & $\begin{array}{c}\text { Double } \\
\text { reheat steam }\end{array}$ \\
\hline $\begin{array}{l}\text { Primary } \\
\text { reheat unit }\end{array}$ & $0.30 \%$ & $0.25 \%$ & -- \\
\hline $\begin{array}{l}\text { Double } \\
\text { reheat unit }\end{array}$ & $0.25 \%$ & $0.15 \%$ & $0.15 \%$ \\
\hline
\end{tabular}

Based on thermal circuit theory of thermal power generation, increasing of primary temperature can effectively increase electric circulating efficiency, that is to say, higher main steam temperature and higher unit electric efficiency. But the increasing of main steam temperature is limited by some factors, especially pipe material. To the steel of high temperature superheater and reheater, and main steam duct, it must consider the smelting technology and capacity of Chinese steel industries. The development of supercritical and ultra supercritical unit must be established in $18 \mathrm{Cr}$ austenitic steel, such as TP347HFG (18 $\mathrm{Cr} 10 \mathrm{NiLNb}$ ) and TP347H, P91 steel. Based on the Chinese practical situation, $580^{\circ} \mathrm{C}$ main steam temperature is appropriate. While, if higher electric efficiency is considered, higher main steam temperature must be adopted, such as $600^{\circ} \mathrm{C}$. Thus the outlet sector of high temperature superheater should use Super TP304H or HR3C non-corrosive steel, and live steam piping P92 steel. P92 steel is a kind of heavy alloyed steel. The chemical performance of P92 steel and P91 steel is similar, but the tungsten of P92 is higher and molybdenum is less. Chemical constitutions of P92 steel and P91 steel saw Table 3.

Table 3 Chemical constitution of P91 and P92 steel (\%)

\begin{tabular}{|c|c|c|c|c|c|}
\hline & $\mathrm{C}$ & $\mathrm{Mn}$ & $\mathrm{P}$ & $\mathrm{S}$ & $\mathrm{Si}$ \\
\hline \multicolumn{6}{|l|}{ P91 } \\
\hline Min content & 0.08 & 0.3 & - & - & 0.2 \\
\hline Max content & 0.12 & 0.6 & 0.02 & 0.01 & 0.5 \\
\hline \multicolumn{6}{|l|}{ P92 } \\
\hline Min content & 0.07 & 0.3 & - & - & - \\
\hline Max content & 0.13 & 0.6 & 0.02 & 0.01 & 0.5 \\
\hline & $\mathrm{Cr}$ & \multicolumn{2}{|c|}{ W } & Mo & V \\
\hline \multicolumn{6}{|l|}{ P91 } \\
\hline Min content & 8.0 & \multicolumn{2}{|c|}{ - } & 0.85 & 0.18 \\
\hline Max content & 9.5 & \multicolumn{2}{|c|}{ - } & 1.05 & 0.25 \\
\hline \multicolumn{6}{|l|}{ P92 } \\
\hline Min content & 8.5 & \multicolumn{2}{|c|}{1.5} & 0.3 & 0.15 \\
\hline Max content & 9.5 & \multicolumn{2}{|c|}{2.0} & 0.6 & 0.25 \\
\hline
\end{tabular}

On the other hand, the yield strength of P92 is lower than that of P91, but its tensile strength is higher than that of P91. Under the temperature $567^{\circ} \mathrm{C}$ to $667^{\circ} \mathrm{C}$, creep strength of $\mathrm{P} 92$ is unvarying, and when temperature is higher $667^{\circ} \mathrm{C}, \mathrm{P} 92$ is better than P91. To develop high parameter ultra supercritical unit, P92 is a good steel to choose. To boiler, when main steam temperature is 
increased form $585^{\circ} \mathrm{C}$ to $605^{\circ} \mathrm{C}$, boiler model can be same, while the steam temperature of rear-screen superheater and finishing superheater is higher, which makes operating temperature of some heating ducts, steam manifolds, pipes of rear-screen superheater higher. The performance of steel is severe. From cost of boiler, when main steam temperature is increased form $585^{\circ} \mathrm{C}$ to $605^{\circ} \mathrm{C}$, the cost of boiler will be increased $1 \%$. Of cause, one-off cost increasing can make long higher economy. If only the manufacture technology of boiler can meet the need of boiler, the increasing of main steam temperature form $585^{\circ} \mathrm{C}$ to $605^{\circ} \mathrm{C}$ is feasible $[9,10]$. From steam turbine manufacture and operation, In Japan, Germany, America, and other country, the manufacture technology of $600^{\circ} \mathrm{C}$ steam turbine has been mature and many operating experience has been got. The unit with main steam temperature being $600^{\circ} \mathrm{C}$ rate can be introduced into China to meet the need of energy-saving and ejection-decreasing.

To generating unit reheat system, based on the theory analysis, the electric efficiency is elated to reheat system. Increasing the reheat system will advance the electric efficiency, see Table 2. Generally speaking, there are two models of reheat system, primary reheat and double reheat. Double reheat system has many merits:

(1) Reduce exhaust steam moisture of low pressure cylinder and cavitation of exhaust stage blade;

(2) Reduce the temperature increasing of reheater. With double reheat system, temperature increasing of reheater is about $200^{\circ} \mathrm{C}$, while with primary reheat system and temperature increasing of reheater is about $280^{\circ} \mathrm{C}$;

(3) Reduce the enthalpy drop of high pressure cylinder. With double reheat system, the enthalpy drop of high pressure cylinder is $300 \mathrm{~kJ} / \mathrm{Kg}$, while with primary reheat system, and the enthalpy drop is $400 \mathrm{~kJ} / \mathrm{Kg}$.

Based on the analysis of reheat system, although there are many merits of double reheat system and higher electric efficiency, its constitution is very complicated. Now, considering the investment of power plant and thermal economy, primary reheat system is appropriate for ultra supercritical unit.

The reheat steam temperature affects on unit efficiency and exhaust steam moisture of low pressure cylinder. The increasing of reheat steam temperature can advance the unit efficiency, and reduce the low pressure cylinder and cavitation of exhaust stage blade. From the safety of high temperature reheater, to increase the reheat steam temperature, the problems of high heat strength of steel, high temperature corrosion of flue gas side and steam oxidation in duct must be paid attention to. When the reheat temperature is up to $600^{\circ} \mathrm{C}$, the wall temperature of finishing reheater could be up to $650^{\circ} \mathrm{C}$. The problems of high temperature corrosion of flue gas side and steam oxidation in duct are obvious. So, the reheat steam temperature generally controlled about $600^{\circ} \mathrm{C}$. In China, to new $1000 \mathrm{MW}$ ultra supercritical unit, its reheat steam flow is controlled $2469.7 \mathrm{t} / \mathrm{h}$, inlet/outlet pressure 5.1 $\mathrm{MPa} / 4.9 \mathrm{MPa}$, inlet/outlet temperature $354.2^{\circ} \mathrm{C} / 603^{\circ} \mathrm{C}$.

\section{CONCLUSIONS}

In order to increase the economy, save the limited coal energy, reduce the pollutant emission, and project environment, high parameter, large capacity, supercritical and ultra supercritical coal-fired power unit is now importantly developed in China. Based on the characteristic of domestic coal-fired unit, to develop supercritical and ultra supercritical coal-fired power unit, the confirmation of thermal parameters is emphasized to be considered. The increasing of thermal parameters could enhance the electric efficiency. To choose the thermal parameters, the overseas technology development and practical engineering outstanding achievement, as well as the capacity of design and manufacture and technology accoutrement of domestic manufactory, material supply and manufacture, and nationalization must be considered. According to various factors, it is appropriate to choose the ultra supercritical unit whose main steam pressure of is less than $27.56 \mathrm{MPa}$, and temperature of main steam and reheat steam is controlled about $600^{\circ} \mathrm{C}$.

\section{ACKNOWLEDGEMENTS}

This work was partially supported by Key Fund of Shanghai Science Technology Committee (No. 071605124).

\section{REFERENCES}

1. ZHENF Ze-min, WEI Shi-rang,YANG Shou-min, Some opinions of the development of large capacity supercritical thermal power generation in China[J]. Thermal Power Generation, (5) (1995), pp.23-30.

2. LU Yan-chang, Devote major efforts to developing supercritical pressure generating units, optimize thermal power mix $[\mathrm{J}]$, Electric Power, 33(1) (2000), pp.1-5.

3. CHENG Xiao-dong, SHI Wei, Large capacity supercritical unit is the trend of clean coal technology in China[J], Power System Engineering, 15(4) (1999), pp.3-10.

4. ZHU Bao-tian, Environmental value and cost evaluation of clean generation $[\mathrm{J}], 21$ Century Electric Power, 2 (2005).

5. ZHANG Le-chuan, Lin-lin, Research on 600MW ultra supercritical steam turboset [J], Heat Power Technics., (2006), (4), pp.1-7.

6. CHE Dong-guang, JIANG Xiao-guo, Summarization of environmental thermal power generation $[\mathrm{J}]$, Boiler Manufacturing, 12 (2006), pp.46-48.

7. CHEN Shu-ping. LI Jian-ping, Practice on Construction of $4 \times 1000 \mathrm{MW}$ Extra Supercritical Unit Project in Huaneng Yuhuan Power Plant $[\mathrm{J}]$, Electric Power Construction, 27(7) (2006), pp.17-21.

8. HU Zhi-hong, GUO Lei, HAO Wei-dong, Discussion on steam purging techniques of a $3033 \mathrm{t} / \mathrm{h}$ ultra-supercritical pressure boiler in zouxian power plant [J], Shandong Electric Power, 6 (2006), pp.3-6.

9. LIU Shao-guang, WU Jin-ming, ZHANG Sheng-cai, et al., Microstructure and Erosional Behavior of Erosion-Resistant Coatings of Super-Critical Boiler Pipes [J], Power Engineering, 26(6) (2006), pp.908-911.

10. ZHAO Zhong-ping, The new materials for supercritical and ultra supercritical power plant units [J], Materials for Mechanical Engineering. 24(6) (2000), pp.1-4. 